НАУКОВИЙ ВІСНИК

Scientific messenger of Livi National University of
Veterinars Meditive and Biotechnologies

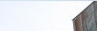

Том 23 № 104

2021
Науковий вісник Аьвівського національного університету ветеринарної медицини та біотехнологій імені С.3. Гжицького. Серія: Ветеринарні науки

Scientific Messenger of Lviv National University of Veterinary Medicine and Biotechnologies. Series: Veterinary sciences doi: $10.32718 /$ nvlvet10412

https://nvlvet.com.ua/index.php/journal

UDC 619:616.98:579.834.111:636.22/.28

\title{
Seasonal and age dynamics of rabbits infestation with spirochetosis in the southern and northern regions of Ukraine
}

Yu. V. Duda, L. V. Koreyba

Dnipro State Agrarian and Economic University, Dnipro, Ukraine

\section{Article info}

Received 29.09.2021

Received in revised form 28.10 .2021

Accepted 29.10.2021

Dnipro State Agrarian and Economic University, Serhiya Yefremova Str., 25, Dnipro, 49000, Ukraine.

Tel.: +38-056-68-33-77

E-mail:lyudkorflk@gmail.com
Duda, Yu. V., \& Koreyba, L. V. (2021). Seasonal and age dynamics of rabbits infestation with spirochetosis in the southern and northern regions of Ukraine. Scientific Messenger of Lviv National University of Veterinary Medicine and Biotechnologies. Series: Veterinary sciences, 23(104), 71-76. doi: $10.32718 /$ nvlvet10412

In the age and seasonal aspect, the peak of spirochetosis infection is observed in rabbits aged 3-4 months in the autumn. A significant increase in the extent and intensity of damage to rabbits by the pathogen spirochetosis was registered from July to October with a peak in September (EI $=69.81 \%$, II = $1080.19 \pm 83.40$ pathogens per $1 \mathrm{~g}$ of feces). The average infestation of rabbits by pathogen Treponema cuniculi was $24.82 \%$. The largest number of sick animals was registered in the Cherkasy region. The goal of the work: determining the influence of age and seasons on the dynamics of the disease of spirochetosis of rabbits of the Californian breed of yard maintenance in different natural and climatic zones. The work was carried out during 2014-2020 in the conditions of a private enterprise for breeding rabbits of the Californian breed, which used cage keeping of animals without air conditioning in compliance with all zoohygienic requirements. Darkfield microscopy was used to detect Treponema cuniculi. The obtained results and calculated averages for animal age and seasons were counted using Microsoft Excel-16. The results of parasitological studies indicate that spirochetosis in rabbits is registered during the year, but the maximum incidence of animals was established in the summer-autumn period of the year, when EI reached $39.92 \%$ and $46.15 \%$, for II $423.57 \pm 52.50 \mathrm{ekz} . \mathrm{g}$ and $628.21 \pm 50.86 \mathrm{ekz} . / \mathrm{g}$. In winter, the rates of animal infestation reached the minimum values $(E I=8.17 \%, I I=12.74 \pm 2.96)$, and with the onset of spring rose again $(E I=13.64 \%, I I=22.73 \pm 3.93)$, in the summer the rise continued $(E I=39.92 \%, I I=423.57 \pm$ $52.50)$, reaching a maximum in autumn $(E I=46.15 \%, I I=628.21 \pm 50.86)$. A significant increase in the extent of damage to rabbits by the causative agent of spirochetosis was registered from July to October with a peak in September $(E I=69.81 \%)$. In November, the infestation decreased sharply and remained low in winter until mid-spring, with the lowest value observed in February (6.86\%). The peak level of spirochetes in rabbits was registered in September and was equal to 1080.19 \pm 83.40 pathogens in $1 \mathrm{~g}$ of feces, and a decrease in the biopotential of parasites is observed in February (II $=9.80 \pm 4.06$ pathogens in $1 \mathrm{~g}$ of feces). It was found that the invasiveness of Treponema cuniculi rabbits increases with age from 2-4 months of age (EI from $88.23 \%$ to $88.89 \%$, with the intensity of the lesion from $794.11 \pm 108.62$ to $1688.89 \pm$ 253.01 pathogens in $1 \mathrm{~g}$ of feces. From 5 months of age to 1-2 years, the rates of infection are gradually reduced: EI to $82.75 \%$, with the intensity of the lesion to $924.14 \pm 109.26$ pathogens in $1 \mathrm{~g}$ of feces. During the studying period, rabbits of private households located in the Forest-Steppe zone were found. Rabbits of private households, which were located in the Forest-Steppe zone, were the most unfavourable for spirochetosis during the study period.

Key words: rabbits, spirochetosis, spirochetes, invasiveness, age dynamics, season of the year, natural and climatic zone.

\section{Сезонна і вікова динаміка показників інвазованості кролів спірохетозом}

Ю. В. Дуда, Л. В. Корейба

Дніпровський державний аграрно-економічний університет, м. Дніпро, Україна 
Результати паразитологічних досліджень вказують на те, шио спірохетоз у кролів реєструється впродовж року, однак максимальна ураженість тварин встановлена у літньо-осінній період року, коли ЕI сягала 39,92 \% та 46,15\%, за II 423,57 \pm 52,50 екз./2 та 628,21 \pm 50,86 екз./2. Узимку показники інвазованості тварин досягали мінімальних значень (EI=8,17\%, II = 12,74 $\pm 2,96)$, а з настанням весни знову підвищувались $(E I=13,64 \%, I I=22,73 \pm 3,93)$, влітку це зростання тривало $(E I=39,92 \%, I I=423,57 \pm$ 52,50), досягаючи максимуму восени $(E I=46,15 \%, I I=628,21 \pm 50,86)$. Значне підвищення екстенсивності ураження кролів збудником спірохетозу зареєстровано з липня по жовтень з піком у вересні $($ EI = 69,81 \%). В листопаді зараженість стрімко знизилась і взимку трималася на низькому рівні до середини весни, при иьому мінімальне значення виявлено у лютому (6,86 \%). Пік рівня ураження кролів спірохетами зареєстрований у вересні і дорівнював 1080,19 \pm 83,40 збудників в 1 г фекалій, а зменшення біопо-

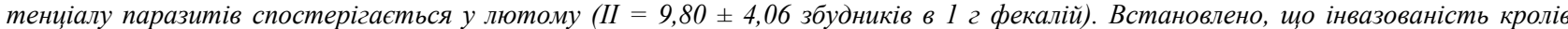

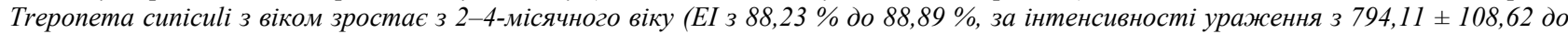
1688,89 \pm 253,01 збудників в 1 г фекалій. 3 5-місячного віку до 1-2 років показники зараженості незначно поступово знижуються: EI до 82,75 \%, за інтенсивності ураження до 924,14 109,26 збудників в 1 г фекалій. Найбільш неблагополучними щодо спірохетозу за період дослідження виявилися кролі приватних домогосподарств, що розташовані на території Лісостепової зони.

Ключові слова: кролі, спірохетоз, спірохета, інвазованість, вікова динаміка, сезон року, природно-кліматична зона.

\section{Ветуп}

Кролівництво - це галузь тваринництва, що забезпечує населення країни м'ясом, хутром та пухом при розведенні одомашнених кролів. За останні роки в Україні кролівництво занепало за причини відсутності сучасних наукових розробок 3 питань повноцінної годівлі, технології утримання кролів, низького рівня племінної роботи і ветеринарного обслуговування.

Кролі дуже чутливі до заразних хвороб. Інфекційні та інвазійні хвороби є небезпечними, оскільки можуть викликати загибель тварин і є причиною недоотримання продукції, розвитку запальних процесів у геніталіях, абортів, народження мертвих та нежиттєздатних кроленят (Kornijenko et al., 2003; Novitska \& Semenko, 2015; Prus et al., 2020; Koreiba et al., 2021). Одним із поширених захворювань, що веде до порушення відтворювальної здатності та тривалої неплідності, є спірохетоз.

Спірохетоз - це хронічне захворювання, що викликається патогенними мікроорганізмами - спірохетами, що призводить до сильного запалення зовнішніх статевих органів та анального отвору (Novitska \& Semenko, 2015; Prus et al., 2020).

Трепонемоз кролів реєструвався в Англії у диких кролів від 20 до 40 \% (Adams et al., 1928), в Бельгії понад 30 \% тварин (Bessemans \& de Geest, 1928). Виявлено, що самки кроликів заражалися легше, ніж самці, та період інкубації варіювався від двох тижнів до двох місяців. Н. Noguchi (1921) в США відмітив у 30 \% кроликів клінічний перебіг захворювання (Noguchi, 1921. За даними J. W. Clark (1970), 15-25 \% кролів інфіковані Treponema cuniculi (Clark, 1970). I. Horvath та інші (1980) стверджували, що хвороба трапляється не лише у домашніх кроликів, а й у диких зайців (Horvath et al., 1980). Захворювання поширене, але практично не трапляється у деяких популяцій диких кроликів в Австралії (Graves et al., 1980). Спірохетоз також реєстрували у ряді кролівничих господарств європейських держав, Америки та Азії, де спостерігалися епізоотії з великим відсотком захворюваності (до 90 \%) (Smith \& Pesetsky, 1967; DiGiacomo et al., 1983).

Treponema cuniculi - спірохета, некультивований вид, який інфікує кроликів і викликає венеричний спірохетоз або трепонематоз (сифіліс кроликів) та захворювання дихальних шляхів (Horvath et al., 1980; Hougen et al., 2009).
Передача збудника захворювання між кроликами відбувається при прямому (підстилка, корми, інвентар та інші предметами довкілля забруднені екскретами хворих тварин) та статевому контакті. Ступінь поширення хвороби залежить від зоогігієнічних та ветеринарно-санітарних умов у приміщеннях для утримання тварин. У крільчатниках поширеність інфекції Treponema cuniculi збільшується зі збільшенням кількості поголів'я кролів (Smith \& Pesetsky, 1967; DiGiacomo et al., 1983; Hougen et al., 2009).

Захворювання характеризується запальним ураженням органів статевої системи, регіонарних лімфатичних вузлів, ділянки лицевого черепа у вигляді блефариту, має хронічний перебіг та супроводжується зниженням показників резистентності організму тварин (Duda, 2019; Prus et al., 2020; Koreiba et al., 2021).

Дисемінація у кроликів відзначається на мордочці, довкола повік, на мошонці та рідше на інших ділянках тіла. Трепонемозні ураження - у вигляді папул, що мають тенденцію до бородавчастого розростання (Novitska \& Semenko, 2015; Duda et al., 2020).

У кролематок класична форма зазвичай починається 3 легкої гіперемії і набряку соромітних губ 3 патологічними виділеннями із статевої щілини. Запалення може охоплювати краніальну частину піхви та слизову оболонку прямої кишки і ануса. У хворих тварин спостерігають періоди поліпшення та погіршення. Іноді ознаки хвороби зникають влітку, а взимку з'являються знову (Kornijenko et al., 2003; Prus et al., 2020; Duda et al., 2020; Koreiba et al., 2021).

Недостатня кількість інформації про вплив сезонів року на поширення спірохетозу серед кролів різного віку потребує дослідження.

Тому мета досліджень полягала у визначенні впливу віку та сезонів року на динаміку захворювання спірохетозом кролів каліфорнійської породи подвірного утримання за різних природно-кліматичних зон.

\section{Матеріал і методи досліджень}

Робота виконувалась впродовж 2014-2020 рр. в умовах приватного підприємства 3 вирощування кролів каліфорнійської породи, в якому використовували кліткове утримання тварин без кондиціонування 3 додержанням всіх зоогігієгичних вимог. Температуру і відносну вологість повітря в приміщені вимірювали за допомогою термогігрометра Walcom HT-350. Пока- 
зники температури і відносної вологості визначали один раз на добу та розраховували середньомісячні значення 3 подальшим підрахунком середнього показника за відповідний сезон. Основний раціон годівлі кролів складав комерційний гранульований комбікорм (ФОП Домашенко Д. І.), вироблений за загальноприйнятою рецептурою для відгодівлі молодняку (рецепт № К-94-22).

Для виявлення Treponema cuniculi застосовували метод темнопольної мікроскопії: відібраний матеріал (фекалій кролів) досліджують під мікроскопом, користуючись конденсором темного поля. Інтенсивністіь інвазованості (II) визначали шляхом підрахунку кількості збудників в 1 г фекалій, використовуючи камеру Мак Мастера (Duda et al., 2019). Екстенсивність інвазованості (ЕI) 3'ясовували як відношення кількості хворих на спірохетоз тварин до загального поголів'я кролів, що виражене у відсотках (Galat et al., 2004).

Отримані результати та розраховані середні показники за віком тварин і за сезонами року розраховували за допомогою програми Microsoft Excel-16.

Достовірність відмінності між показниками за сезонами року перевірялася за t-критерієм Стьюдента. Цифри в таблицях і діаграмі відображають середнє арифметичне значення та стандартні похибки.

\section{Результати та їх обговорення}

В результаті моніторингу мікроклімату в крільчатнику визначили коливання температурновологого режиму в різні сезони року (табл. 1).

\section{Таблиця 1}

Сезонні зміни температури і відносної вологості повітря в крільчатнику

\begin{tabular}{lrrrr}
\hline \multicolumn{1}{c}{ Показники } & \multicolumn{1}{c}{ Зима } & \multicolumn{1}{c}{ Весна } & \multicolumn{1}{c}{ Літо } & Осінь \\
\hline Температура повітря, ${ }^{\circ} \mathrm{C}$ & $+10,6 \pm 0,12$ & $+15,3 \pm 0,19$ & $+23,7 \pm 0,07$ & $+14,1 \pm 0,05$ \\
Відносна вологість повітря, $\%$ & $67,5 \pm 1,01$ & $68,2 \pm 0,61$ & $66,1 \pm 1,14$ & $71,3 \pm 1,31$ \\
\hline
\end{tabular}

Найнижчу середньосезонну температуру повітря в приміщені для утримання кролів реєстрували в зимовий період $\left(+10,6^{\circ} \mathrm{C}\right)$, найвищу - влітку $\left(+23,7^{\circ} \mathrm{C}\right)$, тимчасом як у весняно-осінні сезони температура була більш помірною - без різких відхилень від комфортних значень $\left(+15,3{ }^{\circ} \mathrm{C}\right.$ та $+14,1^{\circ} \mathrm{C}$ відповідно). Середня відносна вологість повітря по кожному сезону року значних перепадів не показала (66,1 до $71,3 \%$ ), але в межах сезону виявляли коливання цього показника від 57,8 \% влітку до 79,5 \% восени.
Відомо, що чисельність паразитів у зовнішньому середовищі залежить від сезону року, що пов'язано 3 коливаннями температур. За результатами проведених копроовоскопічних досліджень кролів із господарств Дніпропетровської та Запорізької областей впродовж 2014-2020 рр. були виявлені певні сезонні закономірності ураженості їх збудниками паразитарних хвороб (табл. 2).

\section{Таблиця 2}

Сезонна динаміка показників інвазованості кролів за спірохетозу $(\mathrm{M} \pm \mathrm{m}, \mathrm{n}=928)$

\begin{tabular}{lcccc}
\hline \multirow{2}{*}{ Показники зараженості } & \multicolumn{4}{c}{ Сезони } \\
\cline { 2 - 5 } & Зима & Весна & Літо & Осінь \\
\hline ЕI, \% & 8,17 & 13,64 & 39,92 & 46,15 \\
II, екз.Г & $12,74 \pm 2,96$ & $22,73 \pm 3,93$ & $423,57 \pm 52,50$ & $628,21 \pm 50,86$ \\
\hline
\end{tabular}

Наведені у табл. 2 результати паразитологічних досліджень вказують на те, що спірохетоз у кролів реєструється впродовж року, однак максимальна ураженість тварин Treponema cuniculi встановлена у літньо-осінній період року, коли ЕІ сягала 39,92 \% та $46,15 \%$, за II 423,57 $\pm 52,50$ екз./Г та $628,21 \pm 50,86$ екз./г. Узимку показники інвазованості кролів досягали мінімальних значень $(\mathrm{EI}=8,17 \%$, II $=12,74 \pm$ $2,96)$, а $з$ настанням весни вони знову зростали $(\mathrm{EI}=$ $13,64 \%$, II $=22,73 \pm 3,93)$, влітку зростання тривало $(\mathrm{EI}=39,92 \%, \mathrm{II}=423,57 \pm 52,50)$, досягаючи максимуму восени $(\mathrm{EI}=46,15 \%$, II $=628,21 \pm 50,86)$.

3 метою отримання точнішої динаміки захворювання кролів нами визначено помісячний рівень ураженості за спірохетозу. Так, дослідженнями встановлено, що динаміка екстенсивності й інтенсивності інвазованості кролів спірохетами різнилась в розрізі місяців (рис. 1).
Значне підвищення екстенсивності ураження кролів збудником спірохетозу зареєстровано з липня по жовтень 3 піком у вересні $(\mathrm{EI}=69,81$ \%). В листопаді зараженість стрімко знизилась і взимку трималася на низькому рівні до середини весни, при цьому мінімальне значення виявлено у лютому $(6,86 \%)$. Аналогічна тенденція - й щодо інтенсивності ураження кролів збудником спірохетозу (рис. 2). Так, пік рівня ураження кролів спірохетами зареєстрований у вересні й дорівнював 1080,19 $\pm 83,40$ збудників в 1 г фекалій, а зменшення біопотенціалу паразитів спостерігається у лютому (II = 9,80 \pm 4,06 збудників в 1 г фекалій).

Проте наші дані різняться щодо сезонного прояву спірохетозу, а саме, за даними Hedley J. (Hedley, 2016), хвороба особливо помітно загострюється восени та взимку, проте ми спостерігали: зараженість в листопаді стрімко знизилась і взимку трималася на низькому рівні до середини весни. 


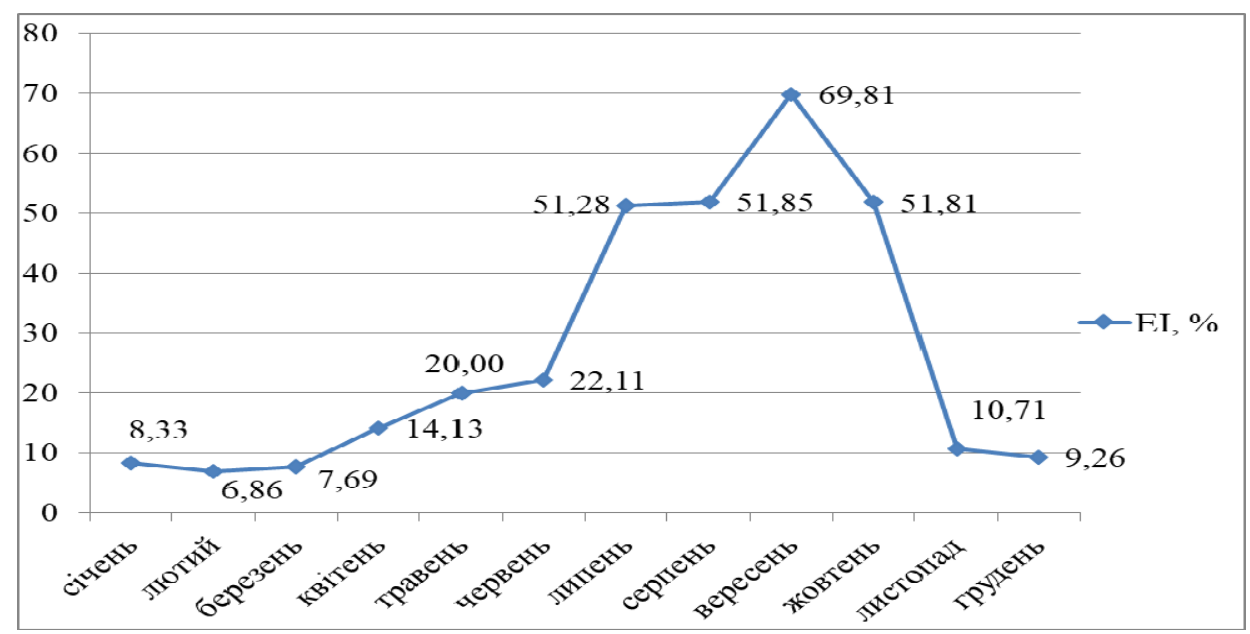

Рис. 1. Динаміка екстенсивності ураження кролів спірохетами по місяцях

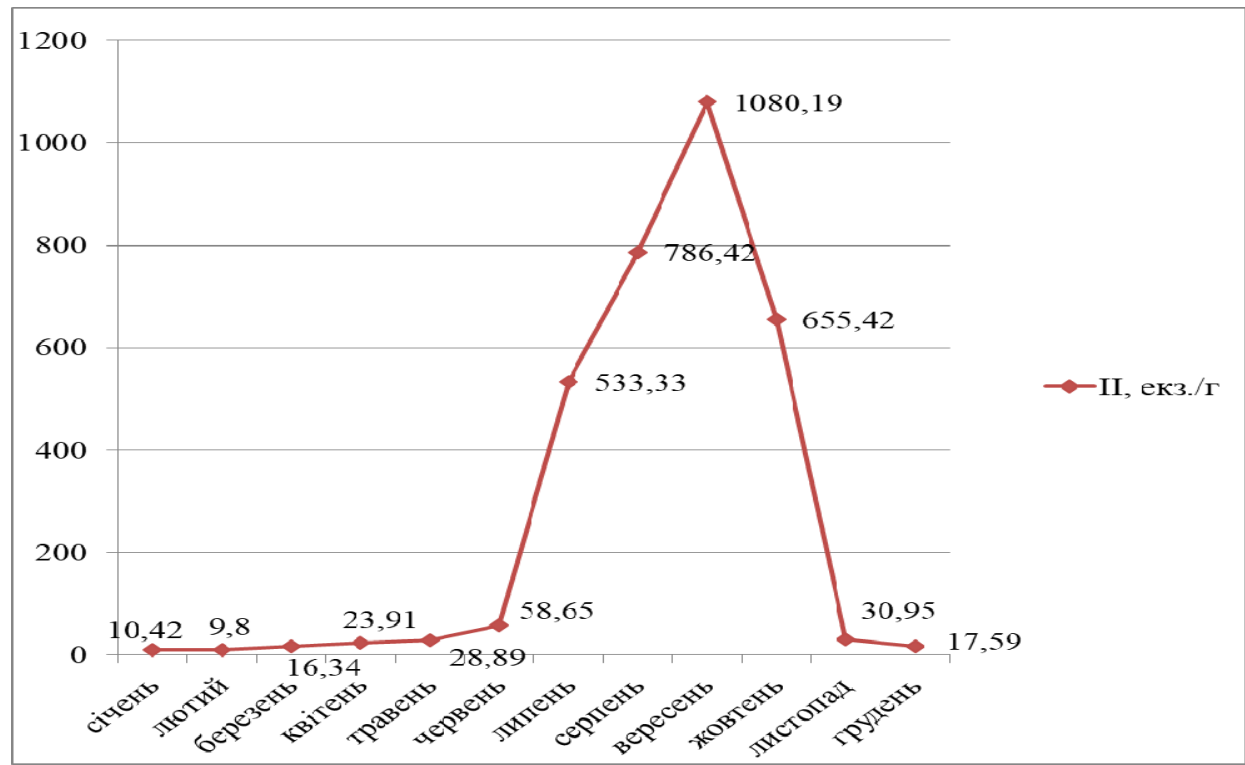

Рис. 2. Динаміка інтенсивності ураження кролів спірохетами по місяцях

Встановлено також залежність між рівнем ураженості кролів спірохетозом та їхнім віком (табл. 3).

Як свідчать дані, наведені у табл. 3, інвазованість кролів Treponema cuniculi з віком зростає. Так, у тварин 1-2-місячного віку реєструються поодинокі випа- дки захворювання (EI $=18,18 \%)$ за інтенсивності ураження 18,18 $\pm 12,20$ збудників в 1 г фекалій.

У кролів 2-4-місячного віку спостерігається стрімке зростання кількості випадків захворювання (ЕI з 88,23 до $88,89 \%$, за інтенсивності ураження з 794,11 $\pm 108,62$ до $1688,89 \pm 253,01$ збудників в 1 г фекалій).

Таблиця 3

Вікова динаміка показників інвазованості кролів за спірохетозу ( $\mathrm{M} \pm \mathrm{m}, \mathrm{n}=928)$

\begin{tabular}{lcccccccc}
\hline \multirow{2}{*}{$\begin{array}{c}\text { Показники } \\
\text { зараженості }\end{array}$} & \multicolumn{7}{c}{ Вікові групи } \\
\cline { 2 - 9 } & $1-2$ & $2-3$ & $3-4$ & $4-5$ & $5-6$ & $6-9$ & $9-12$ & років \\
\hline \multirow{2}{*}{ ЕI, \% } & 18,18 & 88,23 & 88,89 & 88,89 & 86,67 & 83,33 & 85,18 & 82,75 \\
\multirow{2}{*}{ II, екз./Г } & 18,18 & 794,11 & 1688,89 & 1194,44 & 1140,00 & 1072,22 & 985,18 & 924,14 \\
& $\pm 12,20$ & $\pm 108,62$ & $\pm 253,01$ & $\pm 138,49$ & $\pm 124,53$ & $\pm 128,79$ & $\pm 111,79$ & $\pm 109,26$ \\
\hline
\end{tabular}

3 5-місячного віку до 1-2 років показники зараженості незначно поступово знижуються: ЕI до 82,75 \%, за інтенсивності ураження до 924,14 \pm 109,26 збудників в 1 г фекалій. Результати наших досліджень збігаються 3 одержаними результатами С. С. Орлова i С. М. Фріда (1929), які в Росії виявили Treponema cuniculi у $13 \%$ хворих кролів, при цьому вік $55 \%$ самок - більше ніж один рік та $35 \%$ самців були цього ж віку (Orlov \& Frid, 1929). Зараженість кролів збудником Treponema cuniculi за різних кліматичних зон показано в табл. 4. 
Таблиця 4

Інвазованість кролів спірохетозом у домогосподарствах України залежно від природно-кліматичної зони (власні дані; $\mathrm{M} \pm \mathrm{m}, \mathrm{n}=1209$ )

\begin{tabular}{cccccccc}
\hline \multicolumn{9}{c}{2019} & \multicolumn{3}{c}{2020} \\
\hline Полісся & Лісостеп & Степ & У середньому & Полісся & Лісостеп & Степ & У середньому \\
\hline$\underline{23,33}$ & $\underline{33,33}$ & $\underline{22,73}$ & $\underline{25,70}$ & $\underline{24,59}$ & $\underline{33,94}$ & $\underline{19,28}$ & $\underline{23,94}$ \\
163,33 & 301,92 & 254,26 & 257,75 & 195,08 & 261,21 & 193,11 & 212,39 \\
$\pm 41,71$ & $\pm 43,88$ & $\pm 30,24$ & $\pm 22,74$ & $\pm 47,42$ & $\pm 33,35$ & $\pm 25,42$ & $\pm 18,91$ \\
\hline
\end{tabular}

Примітки: числівник - ЕI, \%, знаменник - II

Найбільш неблагополучними щодо спірохетозу за період дослідження виявилися кролі приватних домогосподарств, що розташовані на території Лісостепової зони (Лісостеп). Ця зона розташована між Поліссям i Степом. Клімат зони помірноконтинентальний. Спірохетоз кролів за 2019 і 2020 роки реєструвався у 25,70 \% і 23,94 \% кролів відпо- відно (середня EI = 24,82 \%). Наші дані збігаються 3 дослідженнями J. W. Clark (1970), який стверджував, що 15-25 \% кролів інфіковані Treponema cuniculi (Clark, 1970).

Найбільшу кількість хворих тварин за вказані роки було зареєстровано у Черкаській області - 41,67 \% та 42,10 \% відповідно (табл. 5).

\section{Таблиця 5}

Поширення спірохетозу кролів у домогосподарствах за областями України (власні дані; $\mathrm{M} \pm \mathrm{m}, \mathrm{n}=1209$ )

\begin{tabular}{lcccc}
\hline \multicolumn{1}{c}{ Область } & \multicolumn{3}{c}{ EI, \% } & \multicolumn{2}{c}{ II, збудників в 1 г фекалій } \\
\cline { 2 - 5 } \multicolumn{1}{c}{2019} & 2020 & $116,67 \pm 79,61$ & $109,09 \pm 73,18$ \\
Волинська & 16,67 & 18,18 & $215,69 \pm 38,16$ & $126,88 \pm 22,89$ \\
Дніпропетровська & 20,59 & 16,13 & $229,63 \pm 78,59$ & $252,00 \pm 94,18$ \\
Житомирська & 25,93 & 24,00 & $377,11 \pm 71,45$ & $303,17 \pm 95,92$ \\
Запорізька & 26,51 & 19,05 & $118,18 \pm 62,98$ & $208,33 \pm 93,30$ \\
Івано-Франківська & 27,27 & 33,33 & $212,00 \pm 80,27$ & $197,06 \pm 65,74$ \\
Кіровоградська & 20,00 & 23,53 & $90,00 \pm 46,60$ & $146,15 \pm 78,95$ \\
Львівська & 20,00 & 23,08 & $321,74 \pm 95,05$ & $328,57 \pm 85,84$ \\
Одеська & 21,74 & 23,21 & $88,89 \pm 41,13$ & $84,62 \pm 31,72$ \\
Полтавська & 22,22 & 23,08 & $116,67 \pm 79,61$ & $233,33 \pm 106,03$ \\
Харківська & 16,67 & 22,22 & $88,24 \pm 41,02$ & $95,83 \pm 32,68$ \\
Херсонська & 23,53 & 29,17 & $259,46 \pm 36,90$ & $245,95 \pm 33,05$ \\
Хмельницька & 35,29 & 36,04 & $733,33 \pm 214,06$ & $605,26 \pm 126,72$ \\
Черкаська & 41,67 & 42,10 &
\end{tabular}

Як видно із даних, наведених у табл. 4, серед поголів’я кролів приватних домогосподарств Дніпропетровської, Житомирської і Запорізької областей спостерігали зниження екстенсивності спірохетозної інвазії 3 20,59 \% до 16,13\%, 3 25,93\% до 24,00\% і 3 26,51 \% до 19,05 \% відповідно. У кролів домогосподарств інших областей реєстрували підвищення зараженості означеним збудником, однак одночасно зі збільшенням екстенсивності спірохетозної інвазії у кролів домогосподарств Волинської, ІваноФранківської, Кіровоградської, Полтавської, Хмельницької і Черкаської областей інтенсивність інвазії зменшилась. На наш погляд, особливості сезонновікової динаміки спірохетозної інвазії у всіх домогосподарствах за областями України пояснювались значним впливом довкілля на відносини “паразит-хазяїн”.

\section{Висновки}

У сезонному аспекті пік зараження спірохетозом кролів спостерігається у осінній період. Значне підвищення екстенсивності та інтенсивності ураження кролів збудником спірохетозу зареєстровано 3 липня по жовтень 3 піком у вересні (ЕI = 69,81 \%, II = $1080,19 \pm 83,40$ збудників в 1 г фекалій).
Найвищу інвазованість кролів на спірохетоз виявлено у тварин віком від 3 до 4 місяців. Найвищий відсоток хворих тварин було зареєстровано в 2019 20 pp. у Черкаській області: 41,67-42,10 \% відповідно.

Перспективи подальших досліджень полягає у вивченні показників відтворної здатності кролів за спірохетозу.

Відомості про конфлікт інтересів. Автори стверджують про відсутність конфлікту інтересів щодо їх вкладу та результатів досліджень.

\section{References}

Adams, D. K., Cappell, D. F., \& McCluskie, A.S. (1928). Cutaneous spirochetosis due to Treponema cuniculi in British rabbits. J. Pathol. Bacteriol., 31, 157-161.

Bessemans, A., \& de Geest, B. (1928). Sur quelques propriétés du Treponema cuniculi. C. r. Soc. Biol. Paris., 99, 334.

Clark, J. W. (1970). Serological tests for syphilis in healthy rabbits. Br J Vener Dis., 46(3), 191-197. URL: https://sti.bmj.com/content/sextrans/46/3/191.full.pdf.

DiGiacomo, R. F., Talburt, C. D., Lukehart, S. A., BakerZander, S. A., \& Condon, J. (1983). Treponema paralu- 
is-cuniculi infection in a commercial rabbitry: epidemiology and serodiagnosis. Lab. Anim. Sci., 33(6), 562566. URL: https://pubmed.ncbi.nlm.nih.gov/6363812.

Duda, Y. V. (2019). Klitynnyj imunitet kroliv za vplyvu Treponema cuniculi Naukovo-tehnichnyj bjuleten' DNDKI veterynarnyh preparativ ta kormovyh dobavok i Instytutu biologii' tvaryn NAAN, 20(2), 223-229. doi: 10.36359/scivp.2019-20-2.28 (in Ukrainian).

Duda, Y. V., Prus, M. P., \& Lytvynenko, O. P. (2020). Naukovo-praktychni rekomendacii' $\mathrm{z}$ diagnostyky ta zahodiv borot'by $\mathrm{z}$ osnovnymy shlunkovokyshkovymy parazytozamy kroliv. Dnipro (in Ukrainian).

Duda, Y. V., Shevchyk, R. S., \& Kunjeva, L. V. (2019). Patent Ukrai'ny na korysnu model' 136072 MPK № G01N 1/28 (2006.01). Cposib kil'kisnoi' koproskopichnoi' diagnostyky spirohetozu kroliv iz zastosuvannjam lichyl'noi' kamery Mak-Mastera: zajavnyk i patentovlasnyk Y.V. Duda, R.S. Shevchyk, L.V. Kunjeva; № u 2018 03840; zajavleno 10.04.2018; opublikovano 12.08.2019. Bjul. №15 (in Ukrainian).

Galat, V. F., Berezovs'kyj, A. V., Prus, M.P., \& Soroka, P. M. (2004). Parazytologija ta invazijni hvoroby tvaryn. Praktykum. Kyi'v: Vyshha osvita (in Ukrainian).

Graves, S. R., Edmonds, J. W., \& Shepherd, R. C. (1980). Lack of serological evidence for venereal spirochaetosis in wild Victorian rabbits and the susceptibility of laboratory rabbits to Treponema paraluis-cuniculi. The British Journal of Venereal Diseases, 56(6), 381386. doi: 10.1136/sti.56.6.381.

Hedley, J. (2016). E. cuniculi in rabbits. BSAVA Congress Proceedings, 50-51. doi:10.22233/9781910443446.2.8

Horvath, I., Kemenes, F., Molnar, L., Szeky, A., \& Racz, I. (1980). Experimental syphilis and serological examination for treponematosis in hares. Infect Immun., 27(1), 231-234. doi: 10.1128/iai.27.1.231-234.1980.
Hougen, K. H., Birch-Andersen, A., \& Jensen, H.-J. S. (2009). Electron microscopy of Treponema cuniculi. Acta Pathologica Microbiologica Scandinavica Section B Microbiology and Immunology, 81B(1), 15-26. doi: 10.1111/j.1699-0463.1973.tb02182.x.

Koreiba, L. V., Duda, Y. V., Shevchyk, R. S., \& Vagner, Ja. (2021). Osoblyvosti klinichnogo projavu genital'noi' formy spirohetozu u kroliv. Teorija i praktyka rozvytku vivcharstva Ukrai'ny v umovah jevrointegracii': Materialy V mizhnar. nauk.-prakt. konf., prysvjach. 100-richchju DDAEU 1922-2022 [thesis]. Dnipro, 185-188 (in Ukrainian).

Kornijenko, L. J., Dombrovs'kyj, O. B., Ponomar, S. I., \& Antipov, A. A. (2003). Infekcijni ta invazijni hvoroby kroliv. Bila Cerkva (in Ukrainian).

Noguchi, H. (1921). A note on the venereal spirochetosis of rabbits. J. Amer. med. Ass., 77, 2052. doi: 10.1001/jama.1921.02630520040011.

Novitska, O. V., \& Semenko, O. V. (2015). Zarazni khvoroby kroliv. Kiyiv: TOV NVP "Interservis" (in Ukrainian).

Orlov, S. S., \& Frid, S. M. (1929). Spontannyj spirohetoz krolikov. Zhurnal mikrobiologii, patologii i infekcionyh boleznej, VI(1), 155-172 (in Russian).

Prus, M. P., Duda, Y. V., Korejba, L.V., \& Shevchyk, R. S. (2020). Riven' imunoglobuliniv za vplyv Treponema cuniculi. Aktual'ni problemy veterynarnoi' biotehnologii' ta infekcijnoi' patologii' tvaryn : materialy shhorich. nauk.-prakt. konf. molodyh vchenyh [thesis] IVM NAAN. Kyi'v: CP "Komprynt" (in Ukrainian).

Prus, M. P., Duda, Y. V., Shevchyk, R. S., \& Korejba, L. V. (2020). Spirohetoz kroliv. Tvarynyctvo s'ogodni, 6, 70-72 (in Ukrainian).

Smith, J. L., \& Pesetsky, B. R. (1967). The current status of Treponema cuniculi. Review of the literature. Sexually Transmitted Infections, 43(2), 117-127. doi: $10.1136 /$ sti.43.2.117. 